\title{
QTL Mapping for Cold Tolerance at the Seedling Stage in Rice
}

\author{
Brijesh Kumar Singh ${ }^{1}$, Amit Kumar Singh ${ }^{1}$, Ng. Tombisana Meetei ${ }^{1}$, Arijit Mukherjee ${ }^{2}$ and Nirmal Mandal ${ }^{1 *}$ \\ ${ }^{1}$ Dept. of Agricultural Biotechnology, ${ }^{2}$ Dept. of Genetics \& Plant Breeding, Faculty of Agriculture, \\ Bidhan Chandra Krishi Viswavidyalaya, Mohanpur, West Bengal (741 252), India
}

\section{Article History}

Manuscript No. AR1615

Received in $15^{\text {th }}$ June, 2016

Received in revised form $4^{\text {th }}$ October, 2016

Accepted in final form $6^{\text {th }}$ October, 2016

\section{Correspondence to}

"E-mail: nirman_bckv05@yahoo.com

\section{Keywords}

Rice, seedling stage, cold tolerance, QTL analysis

\begin{abstract}
Rice (Oryza sativa L.) is a nationally and internationally important staple food. It is a cold sensitive crop. Abiotic stress factors are the major constraints not only in rice but also in present agriculture. Cold stress reduces crop yield, their quality and postharvest life. Rice is injured or killed by non-freezing low temperature, and exhibit various symptoms of chilling injury such as chlorosis, necrosis, or growth retardation. In contrast, chilling tolerant species are able to grow at such cold temperatures. Sometimes the plant badly suffers from cold stress during seedling stage when they are grown in winter environment. Consequently, mining cold-tolerant germplasm and mapping cognate genes would provide an opportunity to ameliorate rice yield through marker-assisted selection (MAS). Many quantitative trait loci (QTL) for cold tolerance at seedling stage in rice have been identified and mapped. This information is necessary for understanding of the complex network of molecular changes that are important for chilling and freezing tolerance in crop plants. The development of cold tolerant plants by the introduction of molecular breeding seems to be a viable option to hasten the breeding of 'improved' plants. Intuitively, molecular breeding would be a faster way to mapping of beneficial QTL than through conventional breeding. Although much progress has been accomplished, joint achievement from breeders and plant biotechnologist could expedite the engenderment of cold-tolerant rice plants, and some possible approaches are suggested.
\end{abstract}

\section{Introduction}

Rice (Oryza sativa L.) is a nutritionally important food crop in the World. Around two billion Asians obtain more than $60 \%$ of their required energy from rice (Marathi et al., 2012). It remains today as leading and the most preferred cereal crop in Asia (Maclean et al., 2013). It is also an excellent model plant in biology due to its small genome size $(430 \mathrm{Mb})$, availability of complete genome sequence as well as established gene transfer knowhow and also vast genetic resources. Rice is globally grown on about 165 mha annually with total production of 750 mt (FAO Rice Market Monitor, July, 2015). It ranks second in terms of Worldwide production among cereal crops (FAO Stat, 2014) with cultivation in more than hundred countries. Rice is mainly (90\%) grown in Asian countries (Singh et al., 2013) with China and India being the large scale producers having almost $50 \%$ of the World rice production (EU Rice Economic Fact Sheet, Feb. 2015). India stands second with $155 \mathrm{mt}$ as China occupies the first place in rice with $205 \mathrm{mt}$ in the World's production table of $479.3 \mathrm{mt}$ (USDA, 2013).
In India, with a population of over a billion people, rice is the staple food for almost $65 \%$ (Barah, 2005) of the total population accounting for about $21 \%$ of total global consumption and ranks second among rice consumers of the World (USDA, 2014). The country also accounts for about $21.38 \%$ of global rice production (NITI Aayog, 2015).

World population is increasing at an alarming rate and is expected to reach about 9.7 billion by the end of year 2050 (United Nations, 2015). On the other hand, productivity is diminishing due to the effect of various biotic and abiotic stresses. Biotic and abiotic stresses reduce the average plant productivity by $65 \%$ to $87 \%$ (Bayram et al., 2011). Cold is considered as one of the most important factors limiting the productivity of plants (Levitt, 1980; Larcher, 1995). Plant growth is often negatively influenced by cold stress (Sanghera et al., 2011). More than 15 mha of rice throughout the World suffer from cold damage at one or more growth stages (Zhang et al., 2014). Therefore, minimizing these losses is a major area of responsibility for all nations to cope with the incrementing 
foodstuff requisites.

The development of rice varieties is thus important with increased tolerance to cold stresses, by both molecular breeding and conventional methods; as the molecular breeding in modern agriculture plays a vital role to harness the conventional breeding. Due to the complex polygenic nature of abiotic stresses, attempts have been made by the conventional breeders to improve this trait which has met with little success. Marker assisted breeding in this respect can play an immense role. Quantitative trait loci (QTL) identification followed by its mapping is worthwhile as this creates the enormous scope to transfer it in several mega varieties of rice. Screening of rice genotypes for development of cold tolerant varieties is new possible through the use of molecular markers linked with QTL for cold tolerance and can be eventually used as breeding materials for further improvement programme.

\section{Cold Stress in Rice}

Stress is an influence that is beyond the normal range of homeostatic control (Lerner, 1999) and stresses are classified in two groups viz. biotic and abiotic stress. Biotic stress means damage of plants by living organisms present in the environment e.g., bacteria, viruses, fungi, nematodes etc. Abiotic stress factors or stressors are environmental fluctuations e.g., excess/deficit of water, presence of excessive salt, high wind, temperature, drought, nutrient or heavy metal toxicity, etc. Low temperature is the most important abiotic stress for cereal crops. Rice is more sensitive to cold stress than other cereal crops (Ray et al., 2016). Therefore, in temperate areas, rice productivity is severely affected by cold stress (Xie et al., 2012). The optimum temperature for seed germination and early seedling growth is from 27 to $32^{\circ} \mathrm{C}$. This stage in rice is very important for the seedling growth and establishment, but the rice plants are mostly affected during seedling stage when the temperature falls below $10-13{ }^{\circ} \mathrm{C}$ (Yoshida, 1981). At this stage effects on seedlings can be manifested as poor germination, poor seedling establishment, slow growth, yellowing and drying of leaves, reduced tillering leading to seedling death (Nakagahra et al., 1997; Kaneda et al., 1974; Mackill et al., 1997). Cold stress also affects chlorophyll content and thus interferes photolysis (Kanneganti and Gupta, 2008; Kim et al., 2009). Seedlings are badly affected by cold stress when they are grown in winter environments. Yield loss due to prevailing of low temperature during growing season is a common and unavoidable phenomenon in rice production (Han et al., 2006). Therefore, improvement of seedling's cold tolerance has been one of the most important targets in rice breeding. In Northern and North-eastern parts of India cold stress prevails in winter season usually during December to February and the minimum temperature remains often below $12-15^{\circ} \mathrm{C}$. Sometimes minimum temperatures go below $20^{\circ} \mathrm{C}$ during March and April in some parts of the northern states of India

\section{QTL for Cold Tolerance}

Studies on QTL mapping and linkage disequilibrium (LD) mapping have provided needed information on how gene combinations work under specific environments against particular genetic backgrounds. Progress is being made in developing cold tolerant rice germplasm through conventional breeding (physiological dissection) and the use of molecular tools. Identification of QTL conferring improved cold tolerance may facilitate breeding progress. The availability of saturated molecular maps enables scientists to work for betterment of the complex traits like cold tolerance using QTL (Price et al., 2002). The molecular linkage map for cold tolerance of rice at seedling stage has been reported (Park et al., 2013; Verma et al., 2014; Zhang et al., 2014). Breeders aim to develop rice germplasm that can produce high and stable yields in regions where low temperatures are found. Rice is cultivated virtually all country in the World, from the sea level up to $3000 \mathrm{~m}$ of altitude (Juliano, 1993), making cold tolerance an compulsory trait in many of these regions. Specific objectives include integrating qualities of other varieties into leading varieties. Traits include short-cycle maturity, medium stature, multiple resistances to pests and diseases and good grain quality. In order to develop cold tolerance in rice change of genetic makeup is the most effective approach that has been applied. Screening for cold tolerance in rice is highly complex (Singh et al., 2005), because responses to low temperatures differ between varieties, growth stages and actual temperatures used. For effective selection, the standard screening methodologies (Table 1) described by several scientist to screen rice genotypes for cold response under controlled temperature conditions at germination (seedling) stage are given below.

The Oryza sativa (L.) have two cultivated subspecies: indica and japonica. The indica subspecies includes cultivars better acclimatize to tropical environments likes India, China, and Indonesia, while japonica cultivars are more adapted to temperate climates likes Japan and Korea (Takahashi, 1984). Thus development of cold tolerance in indica rice through breeding with japonica rice has a tremendous scope (Jeong et al., 2000; Mackill and Lei, 1997). Some japonica cultivars viz. Silewah, Lambayque 1, and Padi Labou Alumbis are reported to be cold tolerant (Glaszmann et al., 1990; Saito et al., 2001).

Till recently, the main advancements in the development of cold tolerant rice varieties has been obtained mostly within the japonica cultivars. Therefore, enormous scope is there for improvement of indica type cultivars. This could be done simply by crossing indica genotypes with japonica ones, 


\begin{tabular}{|c|c|c|}
\hline Methodology of screening & Evaluated trait & Reference \\
\hline $\begin{array}{l}10,15,20 \text {, and } 25^{\circ} \mathrm{C} \text { for } 5 \text { to } 30 \text { days (on the } \\
\text { basis of temperature) }\end{array}$ & Germination rate (radicle protrusion) & Bertin et al. (1996) \\
\hline $13^{\circ} \mathrm{C}$ for 28 days and $28{ }^{\circ} \mathrm{C}$ for 7 days & $\begin{array}{l}\text { Germination index and scoring for cold } \\
\text { tolerance } 1-9\end{array}$ & Priyanka et al. (2015) \\
\hline $17^{\circ} \mathrm{C}$ for 7 days & Germination (\%) and its speed & $\begin{array}{l}\text { Sthapit and Witcombe } \\
\text { (1998) }\end{array}$ \\
\hline $13^{\circ} \mathrm{C}$ to $15^{\circ} \mathrm{C}$ for 7 days & Percentage of germination & Lee et al. (2001) \\
\hline $15^{\circ} \mathrm{C}$ for $12-16$ days & Low temperature germinability (LTG) & Sheng et al. (2001) \\
\hline $15^{\circ} \mathrm{C}$ for 10 days & Coleoptile length & Hou et al. (2003) \\
\hline $15^{\circ} \mathrm{C}$ for 6 days & Germination rate & Chen et al. (2006) \\
\hline $\begin{array}{l}13 / 20^{\circ} \mathrm{C} \text { day/night and control condition } 25 / 20 \\
{ }^{\circ} \mathrm{C} \text { day/night } 15 \text { days }\end{array}$ & $\begin{array}{l}\text { Leaf discoloration, SPAD value chlorophyll } \\
\text { content }\end{array}$ & Park et al. (2013) \\
\hline $\begin{array}{l}\text { 12-h light }(15000 \mathrm{LX}) 12 \text {-h dark. The seedlings } \\
\text { were initially exposed to } 14{ }^{\circ} \mathrm{C} \text { for } 2 \mathrm{~h} \text { followed } \\
\text { by } 12^{\circ} \mathrm{C} \text { for } 4 \mathrm{~h} \text { and } 10^{\circ} \mathrm{C} \text { for } 4 \mathrm{~h} \text {. }\end{array}$ & Seedling sensitive & Yang et al. (2013) \\
\hline $10^{\circ} \mathrm{C}$ for 10 days, $10^{\circ} \mathrm{C}$ for 13 days & Seedling survival percentage & Zhang et al. (2005) \\
\hline $12^{\circ} \mathrm{C}$ for 10 days & Seedling vigor & Han et al. (2007) \\
\hline $4{ }^{\circ} \mathrm{C}$ for $48 \mathrm{~h}$ & Cold induced injury & Xiao et al. (2014) \\
\hline $25^{\circ} \mathrm{C}$ for 4 days & Dormancy & Xie et al. (2014) \\
\hline $\begin{array}{l}18-19^{\circ} \mathrm{C} \text { cold-water irrigation (field) } 17-18^{\circ} \mathrm{C} \\
\text { cold-air (glasshouse) }\end{array}$ & Cold sensitive & Jena et al. (2010) \\
\hline $\begin{array}{l}4{ }^{\circ} \mathrm{C} \text { for } 9 \text { days, } 4{ }^{\circ} \mathrm{C} \text { for } 11 \text { days and } 4{ }^{\circ} \mathrm{C} \text { for } 14 \\
\text { days }\end{array}$ & $\begin{array}{l}\text { Cold stress tolerance index and withering } \\
\text { index }\end{array}$ & Juan et al. (2010) \\
\hline $14^{\circ} \mathrm{C}$ for $7 \mathrm{~d}, 11 \mathrm{~d}, 14 \mathrm{~d}$, and $17 \mathrm{~d}$ & Low temperature vigor of germination (LVG) & Han et al. (2006) \\
\hline $\begin{array}{l}50^{\circ} \mathrm{C} \text { for } 48 \mathrm{~h} \text { to break dormancy, } 32^{\circ} \mathrm{C} \text { for } 36 \\
\mathrm{~h}, 5^{\circ} \mathrm{C} \text { for } 10 \text { days, } 20^{\circ} \mathrm{C} \text { for } 10 \text { days to recover }\end{array}$ & Seedling survival & Pan et al. (2015) \\
\hline $13^{\circ} \mathrm{C}$ for 28 days, $28^{\circ} \mathrm{C}$ for 7 days & Coleoptile and radicle length under & Bosetti et al. (2012) \\
\hline $13^{\circ} \mathrm{C}$ for 28 days, $28^{\circ} \mathrm{C}$ for 7 days & $\begin{array}{l}\text { Radicle and coleoptile length and germination } \\
\text { index }\end{array}$ & $\begin{array}{l}\text { Dashtmian et al. } \\
\text { (2013) }\end{array}$ \\
\hline
\end{tabular}

in order to transfer genes for cold tolerance from japonica. However, the combination of desirable characteristics between these two rice groups is difficult to manipulate for consumer acceptance. Molecular markers technology has great potential in molecular breeding of rice harnessing the breeding cycles required for advancing generations.

Although scientists have tried to explore the mechanism of cold tolerance in rice for a long time, its genetic mechanism is still not well understood. Both additive and non-additive gene interaction (da Cruz et al., 2006; Chen et al., 2006) are known to be present for controlling the character. Nagamine (1991) reported that cold tolerance in rice at seedling stages is controlled by a single dominant gene. Still at present rice scientists do not believe that one dominant gene regulates cold tolerance in rice rather this is a complex trait, with many genes interacting and each one having minor effects on the overall cold tolerance phenotypes. Until now, more than 80 QTL (Table 2 and 3) for cold tolerance at seedling stage in rice have been identified (Qian et al., 2000; Andaya and Mackill, 2003; Han et al., 2007; Lou et al., 2007; Jianga et al., 2008; Koseki et al., 2010; Suh et al., 2012).

It is noticeable that most QTL are present in different rice chromosomal regions. The diversity of identified QTL varies for cold tolerance at seedling stage which may be due to the detection of QTL with such different screening procedure of cold tolerance at seedling stage in rice. A major QTL, $q C T S-2$ $(\mathrm{LOD}=15.09)$ was on chromosome 2 flanked by RM561 and RM3 which explained $27.42 \%$ of the total phenotypic variation (Lou et al., 2007) and this region also identified by others with different parental materials.

Side by side different other common QTL ( Figure 1) has also 


\begin{tabular}{|c|c|c|c|c|c|}
\hline Trait & Parents & $\begin{array}{c}\text { Mapping } \\
\text { population }\end{array}$ & $\begin{array}{c}\text { No. of } \\
\text { QTL } \\
\text { identified }\end{array}$ & Salient features & References \\
\hline \multirow{2}{*}{$\begin{array}{l}\text { Low tem- } \\
\text { perature } \\
\text { germina- } \\
\text { bility }\end{array}$} & $\begin{array}{l}\text { JX17 (T) \& } \\
\text { ZYQ8 (S) }\end{array}$ & $127 \mathrm{DH}$ & 2 & $\begin{array}{l}\text { QTL identified on chromosome } 4 \text { and } 9 \text { account } \\
\text { for } 11.1 \text { and } 12.6 \% \text { phenotypic variation with } \\
\text { a LOD score of } 2.85 \text { and } 2.93 \text {, respectively. }\end{array}$ & Sheng et al. (2001) \\
\hline & $\begin{array}{l}\text { Italica Livorno } \\
\text { (T) \& } \\
\text { Hayamasari (S) }\end{array}$ & 122 RILs & 3 & $\begin{array}{l}\text { QTL identified on chromosome } 3 \text { and } 4 \text {. A ma- } \\
\text { jor QTL, } q L T G 3-1 \text { identified on chromosome } \\
3 \text {, accounts for } 35.0 \% \text { phenotypic variation with } \\
\text { a LOD score of } 15.7 \text {. }\end{array}$ & Fujino et al. (2004) \\
\hline \multirow[t]{2}{*}{$\begin{array}{l}\text { Survival } \\
\text { percentage } \\
\text { of seedling }\end{array}$} & $\begin{array}{l}\text { M-202 (T) \& } \\
\text { IR50 (S) }\end{array}$ & 191 RILs & 15 & $\begin{array}{l}\text { QTL identified on chromosome } 1,3,4,6,8 \text {, } \\
10,11,12 \text {. The major QTL, } q \text { CTS } 12 a \text { identified } \\
\text { on chromosome } 12 \text {, accounts for } 40.6 \% \text { phe- } \\
\text { notypic variation with a LOD score of } 20.34 \text {. }\end{array}$ & $\begin{array}{l}\text { Andaya and } \\
\text { Mackill (2003a) }\end{array}$ \\
\hline & $\begin{array}{l}\text { AAV002863 } \\
\text { (T) \& Zhen- } \\
\text { shan97B (S) }\end{array}$ & $\begin{array}{l}193 \mathrm{DH} \\
\text { Lines }\end{array}$ & 5 & $\begin{array}{l}\text { QTL identified on chromosome } 1,2 \text { and } 8 \text {. A } \\
\text { major QTL, } q C T S-2 \text {, identified on chromosome } \\
2 \text { accounts for } 27.42 \% \text { phenotypic variation } \\
\text { with a LOD score of } 15.09 \text {. }\end{array}$ & Lou et al. (2007) \\
\hline \multirow[t]{2}{*}{$\begin{array}{l}\text { Survival } \\
\text { percentage } \\
\text { of seedling }\end{array}$} & $\begin{array}{l}\text { JX17 (T)\& } \\
\text { ZYQ8 (S) }\end{array}$ & $\begin{array}{l}128 \mathrm{DH} \\
\text { lines }\end{array}$ & 4 & $\begin{array}{l}\text { QTL identified on chromosome } 1,2,3 \text { and } 4 \\
\text { contributing } 10.3 \text { to } 12.1 \% \text { phenotypic varia- } \\
\text { tion with a LOD score ranging from } 2.41 \text { to } \\
2.87 \text {. }\end{array}$ & $\begin{array}{l}\text { pujasharma03@ } \\
\text { gmail.com }\end{array}$ \\
\hline & $\begin{array}{l}\text { Asominori (T) } \\
\& \text { IR24 (S) }\end{array}$ & 71 RILs & 3 & $\begin{array}{l}\text { QTL identified on chromosome } 1,5 \text { and } 6 . \text { A } \\
\text { major QTL, } q S C T-1 \text {, identified on chromosome } \\
1 \text { accounts for } 24.51 \% \text { phenotypic variation } \\
\text { with a LOD score of } 4.1 .\end{array}$ & Jiang et al. (2011) \\
\hline $\begin{array}{l}\text { Stable } \\
\text { seedling } \\
\text { establish- } \\
\text { ment }\end{array}$ & $\begin{array}{l}\text { Italica Livorno } \\
\text { (T) \& Arroz Da } \\
\text { Terra (S) }\end{array}$ & $\begin{array}{l}3 \text { mapping } \\
\text { population } \\
\text { of BILs }\end{array}$ & 9 & $\begin{array}{l}\text { QTL identified on chromosome } 1,2,5,6,7 \text {, } \\
10 \text { and } 11 \text { contributing } 10.9 \% \text { to } 25.6 \% \text { phe- } \\
\text { notypic variation with a LOD score ranging } \\
\text { from } 2.9 \text { to } 6.2 \text {. }\end{array}$ & Iwata et al. (2010) \\
\hline $\begin{array}{l}\text { Spikelet } \\
\text { sterility }\end{array}$ & $\begin{array}{l}\text { M-202 (T) \& } \\
\text { IR50 (S) }\end{array}$ & 191 RILs & 8 & $\begin{array}{l}\text { QTL identified on chromosome } 1,2,3,5,6,7,9 \\
\text { and } 12 \text { contrbuting } 11 \text { to } 17 \% \text { phenotypic varia- } \\
\text { tion with a LOD score ranging from } 3.6 \text { to } 6.0 \text {. }\end{array}$ & $\begin{array}{l}\text { Andaya and } \\
\text { Mackill (2003b) }\end{array}$ \\
\hline $\begin{array}{l}\text { Seed fertil- } \\
\text { ity }\end{array}$ & $\begin{array}{l}\text { Hokkai- } \\
\text { PL9(T) \& } \\
\text { Hokkai287(S) }\end{array}$ & $\begin{array}{l}\text { F2 with } \\
288 \text { indi- } \\
\text { viduals }\end{array}$ & 1 & $\begin{array}{l}\text { A major QTL, } q C T B 8 \text {, identified on chromo- } \\
\text { some } 8 \text {, accounts for } 26.6 \% \text { phenotypic varia- } \\
\text { tion with a LOD score of } 10.6 \text {. }\end{array}$ & $\begin{array}{l}\text { Kuroki et al. } \\
(2007)\end{array}$ \\
\hline $\begin{array}{l}\text { Spikelet } \\
\text { fertility }\end{array}$ & $\begin{array}{l}\text { ZL1929-4 (T) } \\
\text { \& Towada (S) }\end{array}$ & $\begin{array}{l}\text { F2 with } \\
2,810 \\
\text { plants }\end{array}$ & 1 & $\begin{array}{l}\text { A major QTL, } q C T B 7 \text {, identified on chromo- } \\
\text { some } 7 \text { accounts for } 9 \text { and } 21 \% \text { phenotypic } \\
\text { variation with a LOD score of } 7.74 \text { and } 11.2 \text { in } \\
\text { F2 and F3 generations, respectively. }\end{array}$ & Zhou et al. (2010) \\
\hline $\begin{array}{l}\text { Per cent } \\
\text { seed set }\end{array}$ & $\begin{array}{l}\text { IR66160-121- } \\
4-4-2(T) \& \\
\text { Geumobyeo (S) }\end{array}$ & $\begin{array}{l}153 \mathrm{~F} 8 \\
\text { RILs }\end{array}$ & 3 & $\begin{array}{l}\text { QTL identified on chromosome } 3,7 \text {, and } 9 \\
\text { contributing } 7.4 \text { to } 9.4 \% \text { phenotypic variation } \\
\text { with a LOD score ranging from } 2.5 \text { to } 4.9 \text {. }\end{array}$ & Suh et al. (2010) \\
\hline $\begin{array}{l}\text { Leaf dis- } \\
\text { coloration, } \\
\text { SPAD } \\
\text { value chlo- } \\
\text { rophyll } \\
\text { content }\end{array}$ & $\begin{array}{l}\text { Milyang } 23 \text { and } \\
\text { Hapcheonaeng- } \\
\text { mi3 }\end{array}$ & 80 RILs & 4 & $\begin{array}{l}\text { QTL identified on chromosome } 2,4 \text { and } 1,5 . \text { A } \\
\text { major QTL, qSPA-4 identified on chromosome } \\
4 \text { accounts for } 16.0 \% \text { phenotypic variation. }\end{array}$ & Park et al. (2013) \\
\hline
\end{tabular}




\begin{tabular}{|c|c|c|c|c|c|}
\hline Trait & Parents & $\begin{array}{c}\text { Mapping } \\
\text { population }\end{array}$ & $\begin{array}{c}\text { No. of } \\
\text { QTL } \\
\text { identified }\end{array}$ & Salient features & References \\
\hline Seedling sensitive & $\begin{array}{l}\text { Nipponbare } \\
\text { (japonica rice) } \\
\text { and } \mathrm{LPBG} \\
\text { (Indica } \text { rice) }\end{array}$ & F3 & 6 & $\begin{array}{l}\text { QTL were mapped on chromosomes } 1,2,2 \mathrm{a}, \\
5,8 \text { and } 10 . \text { The three most significant QTL } \\
\text { on chromosomes } 1,2 \text { and } 8 \text { were validated by } \\
\text { comparison with previous studies }\end{array}$ & $\begin{array}{l}\text { Yang et al. } \\
(2013)\end{array}$ \\
\hline $\begin{array}{l}\text { Low temperature } \\
\text { germinability } \\
\text { (LTG) cold toler- } \\
\text { ance at the seed- } \\
\text { ling stage (CTS) }\end{array}$ & $\begin{array}{l}\text { Daguandao } \\
\text { (japonica) and } \\
\text { IR28 (Indica) }\end{array}$ & 227 RILs & 7 & $\begin{array}{l}\text { QTL identified on chromosome } 3,8 \text {, } \\
11,11,11,11 \text { and } 12 \text { contributing } 5.5 \text { to } 22.4 \% \text {. } \\
\text { phenotypic variation with a LOD score rang- } \\
\text { ing from } 3.0 \text { to } 16.1 \text {. }\end{array}$ & $\begin{array}{l}\text { Wang et al. } \\
(1999)\end{array}$ \\
\hline $\begin{array}{l}\text { Seedling survival } \\
\text { percentage }\end{array}$ & $\begin{array}{l}\text { Lemont } \\
\text { (japonica) and } \\
\text { Teqing (indica) }\end{array}$ & 269 RILs & 5 & $\begin{array}{l}\text { QTL identified on chromosome } 3,3,7,11 \\
\text { and } 11 \text { contributing } 5.5 \text { to } 29.8 \% \text { phenotypic } \\
\text { variation with a LOD score ranging from } 3.25 \\
\text { to } 19.19 \text {. }\end{array}$ & $\begin{array}{l}\text { Hong et al. } \\
(2005)\end{array}$ \\
\hline $\begin{array}{l}\text { Per cent Ratoon- } \\
\text { ing Germinability } \\
\text { (PRG) and Over- } \\
\text { wintering Germi- } \\
\text { nability (POG) }\end{array}$ & $\begin{array}{l}89-1(\mathrm{Gr} 89-1) \\
\text { and Shuhui } 527\end{array}$ & $\begin{array}{l}312 \text { RILs } \\
\text { in F9 }\end{array}$ & 5 & $\begin{array}{l}\text { QTL identified on chromosome } 3,3,7,11 \text { and } \\
11 \text { contributing } 6.7 \text { to } 17.8 \% \text { phenotypic varia- } \\
\text { tion with a LOD score ranging from } 2.7 \text { to } 5.8 \text {. }\end{array}$ & $\begin{array}{l}\text { Zheng et al. } \\
\text { (2012) }\end{array}$ \\
\hline $\begin{array}{l}\text { Leaf yellowing } \\
\text { and leaf rolling }\end{array}$ & $\begin{array}{l}\text { Lijiangxintuan- } \\
\text { heigu (japonica) } \\
\text { and Sanhuang- } \\
\text { zhan-2 (indica) }\end{array}$ & 204 RILs & 9 & $\begin{array}{l}\text { Four QTL on chromosomes } 1,6,9 \text { and } 12 \\
\text { were detected using leaf Yellowing. And } 4 \\
\text { QTL on chromosomes 7, 8, } 9,11 \text { and } 12 \text { were } \\
\text { detected using leaf rolling and per cent seed- } \\
\text { ling survival, two major qCTS-9 and qCTS- } 12 \\
\text { contributing } 15.8 \% \text { and } 14.7 \% \text { phenotypic } \\
\text { variation with a LOD score } 8.0 \text { and } 7.7 \text {. }\end{array}$ & $\begin{array}{l}\text { Zhang et al. } \\
\text { (2014) }\end{array}$ \\
\hline $\begin{array}{l}\text { Novel cold } \\
\text { tolerant cultivars } \\
\text { using molecular } \\
\text { breeding }\end{array}$ & $\begin{array}{l}\text { Danteshwari } \\
\text { and Dagad deshi }\end{array}$ & $\begin{array}{l}122 \text { RILs } \\
\text { in F13 }\end{array}$ & 5 & $\begin{array}{l}\text { QTL identified on chromosome } 1,3,6,9 \text { and } \\
\text { 12. One major QTL present on chromosome } \\
9 \text { had major effect with LOD value of } 9.53 \text {. }\end{array}$ & $\begin{array}{l}\text { Verma et al. } \\
\text { (2014) }\end{array}$ \\
\hline $\begin{array}{l}\text { Root conductivity } \\
(\mathrm{RC})\end{array}$ & $\begin{array}{l}\mathrm{DX} \text { as a cold- } \\
\text { tolerant donor } \\
\text { and Nanjing } 11 \\
(\mathrm{NJ}) \text { recurrent } \\
\text { parent }\end{array}$ & $\begin{array}{l}151 \mathrm{BC} \\
2 \mathrm{~F} 1\end{array}$ & 2 & $\begin{array}{l}\text { QTL identified on chromosome } 10 \text {. QTL, } \\
\text { named qRC } 10-1 \text { and } \mathrm{qRC} 10-2 \text { contributing } \\
9.4 \% \text { to } 32.1 \% \text { phenotypic variation with a } \\
\text { LOD score ranging from } 3.1 \text { to } 6.1 \text {. }\end{array}$ & $\begin{array}{l}\text { Xiao et al. } \\
(2014)\end{array}$ \\
\hline Seedling vigor & $\begin{array}{l}\text { Cross of indica } \\
\text { and japonica } \\
\text { "Milyang 23/ } \\
\text { Jileng } 1\end{array}$ & $200 \mathrm{~F} 3$ & 12 & $\begin{array}{l}\text { QTL were mapped on chromosomes } 1,1,1,1 \text {, } \\
2,2,7,8,8,8,12 \text {, and } 12 \text {. Contributing } 5.2 \text { to } \\
17.9 \% \text { phenotypic variation with a LOD score } \\
\text { ranging from } 2.01 \text { to } 5.02 \text {. }\end{array}$ & $\begin{array}{l}\text { Han et al. } \\
(2007)\end{array}$ \\
\hline $\begin{array}{l}\text { Seed vigor in } \\
\text { germination and } \\
\text { seedling } \\
\text { establishment }\end{array}$ & $\begin{array}{l}\text { Rice (Oryza sa- } \\
\text { tiva L. ssp. in- } \\
\text { dica) cultivars } \\
\text { ZS97 and MH63 }\end{array}$ & 120 RILs & 8 & $\begin{array}{l}\text { QTL were mapped on chromosomes } 1,5,5 \text {, } \\
5,6,6,8 \text { and } 11 \text {. Contributing } 12.6 \text { to } 30.5 \% \\
\text { phenotypic variation with a LOD score rang- } \\
\text { ing from } 5.27 \text { to } 14.8 \text {. }\end{array}$ & $\begin{array}{l}\text { Xie et al. } \\
(2014)\end{array}$ \\
\hline $\begin{array}{l}\text { Cold stress } \\
\text { tolerance index } \\
\text { and withering } \\
\text { index }\end{array}$ & $\begin{array}{l}\mathrm{TN} 1 \text { (indica) va- } \\
\text { riety and Chun- } \\
\text { jiang } 06 \\
\text { (japonica) }\end{array}$ & $\begin{array}{l}120 \mathrm{DH} \\
\text { Lines }\end{array}$ & 5 & $\begin{array}{l}\text { QTL were mapped on chromosomes } 1,2,4,10 \\
\text { and } 11 . \text { Contributing } 10.94 \text { to } 16.43 \mathrm{~F} \text {-value. }\end{array}$ & $\begin{array}{l}\text { Juan et al. } \\
(2010)\end{array}$ \\
\hline
\end{tabular}




\begin{tabular}{|c|c|c|c|c|c|}
\hline Trait & Parents & $\begin{array}{c}\text { Mapping } \\
\text { population }\end{array}$ & $\begin{array}{c}\text { No. of } \\
\text { QTL } \\
\text { identified }\end{array}$ & Salient features & References \\
\hline $\begin{array}{l}\text { Low-temperature } \\
\text { vigor of } \\
\text { germination }\end{array}$ & $\begin{array}{l}\text { Milyang } 23 \\
\text { (indica) and } \\
\text { Jileng } 1 \\
\text { (japonica) rice }\end{array}$ & $200 \mathrm{~F} 2: 3$ & 20 & $\begin{array}{l}\text { QTL were mapped on chromosomes } 1,2,3 \text {, } \\
5,6,7,8 \text { and } 11 \text {. Contributing } 5.3 \text { to } 22.9 \% \\
\text { phenotypic variation with a LOD score } \\
\text { ranging from } 2.12 \text { to } 4.26 \text {. }\end{array}$ & $\begin{array}{l}\text { Han et al. } \\
(2006)\end{array}$ \\
\hline $\begin{array}{l}\text { Combining } \\
\text { microarray with } \\
\text { QTL-mapping }\end{array}$ & $\begin{array}{l}\text { Guichao2 } \\
\text { (indica) and } \\
\text { IL112 } \\
\text { (japonica) }\end{array}$ & $\mathrm{F} 2: 3$ & 7 & $\begin{array}{l}\text { QTL were mapped on chromosomes } 1,2,5,6 \text {, } \\
7 \text { and } 10 \text {. Contributing } 8.0 \text { to } 20 \% \text { phenotypic } \\
\text { variation with a LOD score ranging from } 2.0 \\
\text { to } 4.1 \text {. }\end{array}$ & $\begin{array}{l}\text { Liu et al. } \\
(2013)\end{array}$ \\
\hline $\begin{array}{l}\text { Cold tolerance at } \\
\text { the plumule and } \\
\text { seedling stages }\end{array}$ & A58 and W107 & RILS & 5 & $\begin{array}{l}\text { QTL were mapped on chromosomes } 1,5 \text {, } \\
11,11 \text { and } 112 \text {. Contributing } 13.1 \text { to } 27.0 \% \\
\text { phenotypic variation with a LOD score } \\
\text { ranging from } 2.7 \text { to } 6.8 \text {. }\end{array}$ & $\begin{array}{l}\text { Baruah et al. } \\
(2009)\end{array}$ \\
\hline $\begin{array}{l}\text { Seedling survival } \\
\text { and seed setting }\end{array}$ & Core collection & 174 & 51 & $\begin{array}{l}\text { QTL for cold tolerance were dispersed across } \\
\text { all } 12 \text { chromosomes; } 22 \text { detected at the } \\
\text { germination stage and } 33 \text { at the booting stage. } \\
\text { Eight QTL were identified. About } 46 \% \text { of the } \\
\text { QTL represented new loci. The only QTL } \\
\text { shared between Indica and Japonica for the } \\
\text { same measure was qLTSSvR6-2 for SSvR. } 18 \\
\text { positive and } 21 \text { negative genotypes in Indica } \\
\text { and } 19 \text { positive and } 24 \text { negative genotypes in } \\
\text { Japonica identify for cold tolerance }\end{array}$ & $\begin{array}{l}\text { Pan et al. } \\
(2015)\end{array}$ \\
\hline $\begin{array}{l}\text { Agricultural } \\
\text { performances in } \\
\text { cold airs }\end{array}$ & $\begin{array}{l}\text { Milyang23 } \\
\text { (O. sativa } \mathrm{ssp} \text {. } \\
\text { indica) \& Hap- } \\
\text { cheonaengmi3 }\end{array}$ & 80 RILs & 14 & $\begin{array}{l}\text { QTL were mapped on chromosomes } 1,5 \text {, } \\
11,11 \text { and } 112 \text {. Contributing } 5.8 \text { to } 32.8 \% \\
\text { phenotypic variation with a LOD score } \\
\text { ranging from } 2.6 \text { to } 4.5 \text {. }\end{array}$ & $\begin{array}{l}\text { Oh et al. } \\
(2004)\end{array}$ \\
\hline $\begin{array}{l}\text { Main effects } \\
\text { of QTL with } \\
\text { regard to their } \\
\text { interactions with } \\
\text { environments }\end{array}$ & $\begin{array}{l}\text { Dasanbyeo } \\
\text { (indica) and } \\
\text { TR22183 } \\
\text { (japonica) }\end{array}$ & RILs & 57 & $\begin{array}{l}\text { QTL were mapped on all } 12 \text { chromosomes. } \\
\text { Contributing } 13.2 \text { to } 29.1 \% \text { phenotypic } \\
\text { variation with a LOD score ranging from } 2.2 \\
\text { to } 8.8 \text {. }\end{array}$ & $\begin{array}{l}\text { Jiang et al. } \\
\text { (2011) }\end{array}$ \\
\hline
\end{tabular}

been found by several scientists for cold tolerance at seedling stage in rice, viz. qSPA-1 and qCTS-1 on chromosome 1 (Park et al., 2013; Liu et al., 2013; Juan et al., 2010); qCTS-2 on chromosome 2 (Lou et al., 2007; Liu et al., 2013); qCTS-12 on chromosome 12 (Zhang et al., 2014; Suh et al., 2013; Anandya et al., 2006). Likewise, Suh et al. (2013); Verma et al. (2014) also found approximately the same region of Chromosome 3 with LOD score greater than 3 . So the flanking marker of this region can be used for screening of the rice Germplasm for cold tolerance at seedling stage. It is evident that a remarkable work has been done in the understanding of cold tolerance in rice plants. Among the abiotic stresses cold stress is a major constrain to stability in production and yield under cold rice ecosystem.

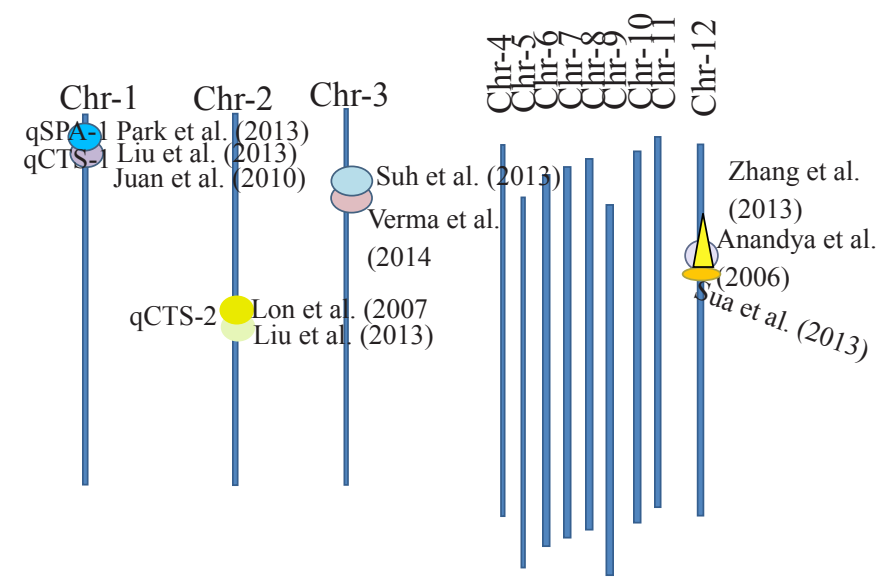

Figure 1: Common QTL for cold tolerance at seedling stage of rice observed by different scientists in different population 


\begin{tabular}{|c|c|c|c|c|c|c|}
\hline $\begin{array}{l}\text { Sl. } \\
\text { No. }\end{array}$ & QTL name & Marker name & $\begin{array}{c}\text { Chr. } \\
\text { no. }\end{array}$ & $\mathrm{Cm}$ & LOD & Source \\
\hline 1. & qspa4 & RM6333-RM6368 & 1 & 147.2 & - & Park et al. (2013) \\
\hline 2. & qspa4 & RM6333-RM6368 & 1 & - & - & Andaya and Tai (2007) \\
\hline 3. & Qspa-1 & RM323-RM428 & 1 & $1.0-19.3$ & - & Park et al. (2013) \\
\hline 4. & qcts-1a & RM84-RM522 & 1 & $26.2-40.6$ & 6.33 & Lou et al. (2007) \\
\hline 5. & qcts-1-b & RM493-RM9 & 1 & $79.7-92.4$ & 6.65 & Lou et al.(2007) \\
\hline 6. & qcts-1-c & RM315-RM472 & 1 & - & 8.03 & Lou et al. (2007) \\
\hline 7. & - & RM265-RM104 & 1 & $155.9-186.6$ & 4.33 & Zhi et al. (2004) \\
\hline 8. & - & RM3475 & 1 & - & - & Suh et al, (2013) \\
\hline 9. & qSPA-1 & RM428-RM323 & 1 & $19.3-$ & - & Park et al. (2013) \\
\hline 10. & - & RM449-RM5 & 1 & $78.4-94.9$ & 3.24 & Verma et al, (2014) \\
\hline 11. & Qcts1-1 & RM1282-RM3426 & 1 & $4.2-19.9$ & 19.2 & Liu et al. (2013) \\
\hline 12. & qwI-1 & RM1282-RM428 & 1 & $4.2-19.9$ & - & Juan et al. (2010) \\
\hline 13. & qcts-1 & RG811-RM562 & 1 & - & 3.9 & Zhang et al. (2013) \\
\hline 14. & qcts-1 & RM297-RM319 & 1 & - & - & Andaya (2003) \\
\hline 15. & Qcts-2 & RM561-RM341 & 2 & $74.1-82.7$ & 15.09 & Lou et al. (2007) \\
\hline 16. & Qcst-2 & RM341-RM6318 & 2 & $82.7-96.6$ & 4.1 & Liu et al. (2013) \\
\hline 17. & - & RM-5764 & 2 & 7.9 & - & Suh et al. (2013) \\
\hline 18. & Qspa-2 & RM423-RM555 & 2 & $28.7-34.7$ & - & Park et al. (2013) \\
\hline 19. & Q11d-2 & RM5607-RM208 & 2 & $142.5-186.4$ & - & Juan et al. (2010) \\
\hline 20. & Qcivg-1 & RM29-RM118 & 2 & - & - & Long et al. (2006) \\
\hline 21. & Qsct-3 & RM156-RM16 & 3 & - & 4.25 & Zhang et al. (2013) \\
\hline 22. & Qlvg 3 & RM251-RM282 & 3 & - & 4.26 & Zhi et al. (2006) \\
\hline 23. & Qspa-4 & RM335-RM518 & 4 & $21.5-25.5$ & - & Park et al. (2013) \\
\hline 24. & Q9d-4 & RM3735-RM252 & 4 & $81.7-99.0$ & - & Juan et al. (2010) \\
\hline 25. & Qspa-5 & RM161 & 5 & 78.7 & - & Park et al. (2013) \\
\hline 26. & Qcst-5 & RM305-RM3620 & 5 & $96.9-104$ & - & Liu et al. (2013) \\
\hline 27 & Qcst-6 & RM161-RM340 & 6 & - & 2.0 & Liu et al. (2013) \\
\hline 28. & Qcts-6 & RM30-RM400 & 6 & - & 3.1 & Zhang et al. (2013) \\
\hline 29. & Qcst-7 & RM6081-RM3826 & 7 & - & 2.4 & Zhang et al. (2005) \\
\hline 30. & Qsct-7 & RM336-RM10 & 7 & - & 3.33 & Zhang et al. (2005) \\
\hline 31. & Qlvg 7-1 & RM51-RM298 & 7 & - & 4.12 & Zhi et al. (2006) \\
\hline 32. & Qlvg 7-2 & RM336-RM118 & 7 & - & 2.63 & Zhi et al. (2006) \\
\hline 33. & Qcts-8 & RM506-RM152 & 8 & - & 5.59 & Lou et al. (2007) \\
\hline 34. & Qcts-8 & RM310-CG11 & 8 & - & 3.9 & Zhang et al. (2014) \\
\hline 35. & Qcts-8 & RM282-RM230 & 8 & - & - & Andaya et al. (2003) \\
\hline 36. & - & RM256 & 8 & - & - & Suh et al. (2013) \\
\hline 37. & Qcts-9 & RM6854-RM566 & 9 & - & 6.8 & Zhang et al. (2014) \\
\hline 38. & - & HvSSR9-7- HvSSR9-19 & 9 & $4.35-10.50$ & - & Verma et al. (2014) \\
\hline 39. & Qcts-9 & RM328-RM245 & 9 & $82.4-112.3$ & - & Zhi et al. (2004) \\
\hline 40. & QRC10-1 & RM1108-RM171 & 10 & $55.3-73.0$ & - & Xiao et al. (2014) \\
\hline 41. & QCR 10-2 & RM25570-RM304 & 10 & $72.3-73.0$ & - & Xiao et al. (2014) \\
\hline
\end{tabular}




\begin{tabular}{lcccccc}
\hline Sl. & QTL name & Marker name & Chr. & Cm & LOD & Source \\
No. & & no. & & & \\
42. & - & RM590 & 10 & 117.2 & - & Suh et al. (2013) \\
43. & QCST-10 & RM33 & 10 & - & 2.4 & Liu et al. (2014) \\
44. & Qcst-10 & RM271-RM258 & 10 & $59.4-70.8$ & - & Juan et al. (2010) \\
45. & qRC10-1 & RM171-RM1108 & 10 & - & 3.1 & Xiao et al. (2014) \\
46. & qRC10-2 & RM25570-RM304 & 10 & - & 6.1 & Xiao et al. (2014) \\
47. & Q14d-11 & RM286-RM1812 & 11 & $0.0-11.0$ & - & Juan et al. (2010) \\
48. & Qsct-11 & RM202-RM209 & 11 & $54.0-73.9$ & 19.19 & Zhang et al. (2005) \\
49. & Qcts-11 & RM224-RM2136 & 11 & $117.9-120.1$ & 3.0 & Zhang et al. (2013) \\
50. & - & RM512 & 12 & 43.2 & - & Suh et al. (2013) \\
51. & Qcts12-a & RM101-RM292 & 12 & - & - & Andaya et al. (2002) \\
52. & Qcts-12 & RM27628-RM397 & 12 & $23.5-47.06$ & 5.3 & Zhang et al. (2013) \\
53. & Qcsh-12 & RM270-RM17 & 12 & $91.3-109.1$ & - & Han et al. (2007) \\
54. & - & HvSSR12-35- HvSSR12-40 & 12 & $19.9-22.6$ & - & Verma et al. (2014) \\
\hline
\end{tabular}

\section{Conclusion}

The improvement of rice cultivars with low temperature tolerance is an important task in increasing productivity. The complex nature of cold tolerance, lack of understanding of its inheritance and difficulty of effective cold tolerance screening complicate the development of cold tolerance varieties. The development of cold tolerant plants by the introduction of molecular breeding seems to be a meaningful approach to hasten the breeding of improved plants. Intuitively, molecular breeding would be a faster way to mapping of beneficial QTL than through conventional breeding.

\section{References}

Andaya, V.C., Mackill, D.J., 2003a. Mapping of QTL associated with cold tolerance during the vegetative stage in rice. Journal of Experimental Botany 54, 2579-2585.

Andaya, V.C., Mackill, D.J., 2003b. QTL conferring cold tolerance at the booting stage of rice using recombinant inbred lines from a japonica $\times$ indica cross. Theoretical and Applied Genetics 106, 1084-1090.

Andaya, V.C., Tai, T.H., 2006. Fine mapping of the qCTS12 locus, a major QTL for seedling cold tolerance in rice. Theoretical and Applied Genetics 113, 467-475.

Andaya, V.C., Tai, T.H., 2007. Fine mapping of the qCTS4 locus associated with seedling cold tolerance in rice (Oryza sativa L.). Molecular Breeding 20, 349-358.

Barah, B.C., 2005. Dynamics of rice economy in india: emerging scenario and policy options. National bank for agriculture and rural development Mumbai. Department of Economic Analysis and Research. Occasional Paper 47.

Baruah, A.R., Ishigo-Oka, N., Adachi, M., Oguma, Y.,
Tokizono, Y., 2009. Cold tolerance at the early growth stage in wild and cultivated rice. Euphytica 165, 459-470.

Bayram, S., Süleyman, S., Elif, Y., 2011. Drought and oxidative stress. African Journal of Biotechnology 10, 11102-11109.

Bertin, P., Kinet, J.M., Bouharmont, J., 1996. Evaluation of chilling sensitivity in different rice varieties. Relationship between screening procedures applied during germination and vegetative growth. Euphytica 89, 201-210.

Bosetti, F., Montebelli, C., Dionisia, A., Novembre, L.C., Chamma, H. P., Pinheiro, J.B., 2012. Genetic variation of germination cold tolerance in Japanese rice germplasm. Breeding Science 62, 209-215.

Chen, L., Lou, Q., Sun, Z., Xing, Y., Yu, X., Luo, L., 2006. QTL mapping of low temperature on germination rate of rice. Rice Science 13, 93-98.

da Cruz, R.P., Milach, S.C.K., Federizzi, L.C., 2006. Inheritance of rice cold tolerance at the germination stage. Genetics and Molecular Biology 29, 314-320.

Dashtmian, F.P., Hosseini, M.K., Esfahani, M., 2013. Methods for rice genotypes cold tolerance evaluation at germination stage. International Journal of Agriculture and Crop Sciences 5, 2111-2116.

EU Rice Economic Fact Sheet, 2015. Economics and analysis of agricultural markets. European commission directorate-general for agriculture and rural development. February 26, 2015, p 2. http://ec.europa.eu/agriculture/ cereals/trade/rice/economic-fact-sheet_en.pdf.

FAO Rice Market Monitor, 2015. Rice market monitor, production international trade rice utilization and domestic prices. FAO July 2015, volume xviii, issue no. 2 .

FAOStat, 2014. Food and agricultural commodities production: 
commodities by regions. FAOStat, Aug 2014, volume 18 . Fujino, K., Sekiguchi, H., Sato, T., Kiuchi, H., Nonoue, Y., Takeuchi, Y., Ando, T., Lin, S.Y., Yano, M., 2004. Mapping of quantitative trait loci controlling lowtemperature germinability in rice (Oryza sativa L.). Theoretical and Applied Genetics 108, 794-799.

Glaszmann, J.C., Kaw, R.N., Khush, G.S., 1990. Genetic divergence among cold-tolerant rices (Oryza sativa L.). Euphytica 45, 95-104.

Han, L.Z., Qiao, Y..L., Zhang, S.Y., Zhang, Y.Y., Cao, G.L., Kim, J.W., Lee, K., Koh, H.J., 2007. Identification of quantitative trait loci for cold response of seedling vigor traits in rice. Journal of Genetics and Genomics 34, 239-246.

Han, L.Z., Zhang, S.Y., 2004. Methods of characterization and evaluation of cold tolerance in rice. Journal of Plant Genetic Resources 5, 75-80.

Han, L.Z., Zhang, Y.Y., Qiao, Y.L., Cao, G.L., Zhang, S.Y., Kim, J.H., Koh, H.J., 2006. Genetic and QTL analysis for low temperature vigor of germination in rice. Acta Genetica Sinica 33, 998-1006.

Hou, M.Y., Jiang, L., Wang, C.M., Wan, J.M., 2003. Detection and analysis of QTL for low temperature germinability in rice (Oryza sativa L.). Rice Genetics Newsletter 20, $52-55$.

Iwata, N., Fujino, K., 2010. Genetic effects of major QTL controlling low-temperature germinability in different genetic backgrounds in rice (Oryza sativa L.). Genome 53, 763-768.

Jena, K.K., Kim, S.M., Suh, J.P., Kim, Y.G., 2010. Development of cold-tolerant breeding lines using QTL analysis in rice. In: Rice genetic diversity and improvement, $2^{\text {nd }}$ Africa Rice Congress, Bamako, Mali., March, 22-26.

Jeong, E.G., Yea, J.D., Baek, M.K., Moon, H.P., Choi, H.C., Yoon, K.M., Ahn, S.N., 2000. Estimation of critical temperature for traits related to cold tolerance in rice. Korean Journal of Breeding 32, 363-368.

Jiang, W., Jin, Y.M., Lee, J., Lee, K.I., Piao, R., Han, L., Shin, J.C., Jin, R.D., Cao, T., Pan, H.Y., Xinglin, D., Koh, H.J., 2011. Quantitative trait loci for cold tolerance of rice recombinant inbred lines in low temperature environments. Molecules and Cells 32, 579-587.

Jianga, L., Xuna, M., Wangb, J., Wan, J., 2008. QTL analysis of cold tolerance at seedling stage in rice (Oryza sativa L.) using recombination inbred lines. Journal of Cereal Science 48, 173-179.

Juan, J.Z., Xiang, Z.Y., Li, Z.D., Yong, M.L., Ming, L.X., Xin, L.B., Deng, Y.C., 2010. Identification of QTL for rice cold tolerance at plumule and 3-leaf seedling stages by using QTL network software. Rice Science 17, 282-287.
Juliano, B.O., 1993. Rice in human nutrition. International Rice Research Institute, Los Banos, Philippines, 1-15.

Kaneda, C., Beachell, H.M., 1974. Response of indicajaponica rice hybrids to low temperatures. SABRAO Journal 6, 17-32.

Kanneganti, V., Gupta, A.K., 2008. Overexpression of OsiSAP8, a member of stress associated protein (SAP) gene family of rice confers tolerance to salt, drought and cold stress in transgenic tobacco and rice. Plant Molecular Biology 66, 445-462.

Kim, S.J., Lee, S.C., Hong, S.K., An, K., An, G., Kim, S.R., 2009. Ectopic expression of a cold responsive OsAsr1 cDNA gives enhanced cold tolerance in transgenic rice plants. Molecules and Cells 27, 449-458.

Koseki, M.N., Kitazawa, S., Yonebayashi, Y., Maehara, Z., Wang, X., Minobe, Y., 2010. Identification and fine mapping of a major quantitative trait locus originating from wild rice, controlling cold tolerance at the seedling stage. Molecular Genetics and Genomics 284, 45-54.

Kuroki, M., Saito, K., Matsuba, S., Okogami, N.Y., Shimizu, H., Ando, I., Sato, Y., 2007. A quantitative trait locus for cold tolerance at the booting stage on rice chromosome 8 . Theoretical and Applied Genetics 115, 593-600.

Larcher, W., Schulze, Caldwell, M.M., 1995. Photosynthesis as a tool for indicating temperature stress events. Ecophysiology of Photosynthesis, 261-274.

Lee, M.H., Fukai, S., Basnayake, J., 2001. Increased lowland rice production in the Mekong Region. In: Proceedings of an international workshop, Vientiane, Laos, $30^{\text {th }}$ October to $2^{\text {nd }}$ November, 2000 at Australian Center for International Agricultural Research, Canberra, Australia on Low temperature tolerance in rice: The Korean Experience, 109-117.

Lerner, H.R., Marcel, D., 1999. Introduction to the response of plants to environmental stresses. In: Plant Responses to Environmental Stresses. New York, 1-26.

Levitt, J., 1980. Responses of Plants to Environmental Stresses, 2nd ed. New York, Academic Press.

Liu, F.X., Xu, W.Y., Song, Q., Tan, L.B., Liu, J.Y., Zhu, Z.F., Fu, Y.C., Su, Z., Sun, C.Q., 2013, Microarray-assisted fine-mapping of quantitative trait loci for cold tolerance in rice. Molecular Plant 6, 757-767.

Lou, Q., Chen, L., Sun, Z., Xing, Y., Li, J., Xu, X., Mei, H., Luo, L., 2007. A major QTL associated with cold tolerance at seedling stage in rice (Oryza sativa L.). Euphytica 158, 87-94.

Mackill, D.J., Lei, X.M., 1997. Genetic variation for traits related to temperate adaptation of rice cultivars. Crop Science 37, 1340-1346.

Maclean, J.L., Hardy, B., Hettel, G.P., 2013. International 
Rice Research Institute: Los Banos, Philippines, Rice Almanac, $4^{\text {th }}$ edn., 298.

Marathi, B., Guleria, S., Mohapatra, T., Parsad, R., Mariappan, N., Kurungara, K.V., Singh, S., Atwal, Prabhu, K.V., Singh, N. K., Singh, A.K., 2012. QTL analysis of novel genomic regions associated with yield and yield related traits in new plant type based recombinant inbred lines of rice (Oryza sativa L.). BMC Plant Biology 12, 13.

Nagamine, T., Nakagahra, M., 1991. Genetic control of chilling injury in rice seedlings detected by low temperature treatment. In: Proceedings of the International Rice Genetics Symposium. IRRI, Los Banos, Philippines, 737-739.

Nakagahra, M., Okuno, K., Vaughan, D., 1997. Rice genetic resources: History, conservation, investigative characterization and use in Japan. Plant Molecular Biology 35, 69-77.

NITI Aayog, 2015. Raising agricultural productivity and making farming remunerative for farmers. National Institution for Transforming India. 16 $6^{\text {th }}$ December, 2015.

Oh, C.S., Choi, Y.H., Lee, S.J., Yoon, D.B., Moon, H.P., Ahn, S.N., 2004. Mapping of quantitative trait loci for cold tolerance in weedy rice. Breeding Science 54, 373-380.

Pan, Y., Zhang. H., Zhang, D., Li, J., Xiong, H., Yu, J., 2015. Genetic analysis of cold tolerance at the germination and booting stages in rice by association mapping. PLoS ONE 10, e0120590.

Park, I.K., Oh, C.S., Kim, D.M., Yeo, S.M., Ahn, S.N., 2013. QTL Mapping for cold tolerance at the seedling stage using introgression lines derived from an intersubspecific cross in rice. Plant Breeding and Biotechnology 1, 1-8.

Price, A.H., Cairns, J.E., Horton, P., Jones, H.G., Griffiths, H., 2002. Linking drought resistant mechanisms to drought avoidance in upland rice using a QTL approach: progress and new opportunities to integrate stomatal and mesophyll responses. Journal of Experimental Botany 53, 989-1004.

Priyanka, K., Jaiswal, H.K., Waza, S.A., Sravan, T., 2015. Response of rice seedlings to cold tolerance under boro conditions. SABRAO Journal of Breeding and Genetics 47, 185-190.

Qian, Q., Zeng, D.L., He, P., Zheng, X.W., Chen, Y., 2000. QTL analysis of the rice seedling cold tolerance in a double haploid population derived from anther of a hybrid between indica and japonica rice. Chinese Science Bulletin 5, 448-453.

Ray, B.P., Rahman K.M., Hossain, M.E., Sarker, P.C., 2016. DNA extraction protocol without liquid nitrogen of cold tolerant rice. World Journal of Biology and Medical Sciences 3, 59-67.
Saito, K., Miura, K., Nagano, K., Hayano, S.Y., Araki, H., Kato, A., 2001. Identification of two closely linked quantitative trait loci for cold tolerance on chromosome 4 of rice and their association with anther length. Theoretical and Applied Genetics 103, 862-868.

Sanghera, G.S., Wani, S.H., Hussain, W., Singh, N.B., 2011. Engineering cold stress tolerance in crop plants. Current Genomics 12, 30-43.

Sheng, T., Dali, Z., Qian, Q., Yasufumi, K., Danian, H., Lihuang, Z., 2001. QTL analysis of rice low temperature germinability. Chinese Science Bulletin 46, 1800-1803.

Singh, A.K., Meena, M.K., Bharati, R.C., Gade, R.M., 2013. Effect of sulphur and zinc management on yield, nutrient uptake, changes in soil fertility and economics in rice (Oryza sativa)-lentil (Lens culinaris) cropping system. Indian Journal of Agricultural Sciences 83, 344-348.

Singh, R.P., Brennan, J.P., Farrell, T., Williams, R., Reinke, R., Lewin, L., 2005. Economic analysis of breeding for improved cold tolerance in rice in Australia. Australasian Agribusiness Review 13, 1-9.

Sthapit, B.R., Witcombe, J.R., 1998. Inheritance of tolerance to chilling stress in rice during germination and plumule greening. Crop Science 38, 660-665.

Suh, J.P., Cho, Y.C., Lee, J.H., Lee, S.B., Jung, J.Y., Choi, I.S., Kim, M.K., Kim, C.K., Jena, K.K., 2013. SSR analysis of genetic diversity and cold tolerance in temperate rice germplasm. Plant Breeding and Biotechnology 1, $103-110$.

Suh, J.P., Jeung, J.U., Lee, J.I., Choi, Y.H., Yea, J.D., Virk, P.S., Mackill, D.J., Jena, K.K., 2010. Identification and analysis of QTL controlling cold tolerance at the reproductive stage and validation of effective QTL in cold-tolerance genotypes of rice (Oryza sativa L.). Theoretical and Applied Genetics 120, 985-995.

Suh, J.P., Lee, C.K., Lee, J.H., Kim, J.J., Kim, S.M., Cho, Y.C., Park, S.H., Shin, J.C., Kim, Y.G., Jena, K.K., 2012. Identification of quantitative trait loci for seedling cold tolerance using RILs derived from a cross between japonica and tropical japonica rice cultivars. Euphytica 184, 101-108.

Takahashi, N., Tsunoda, S., 1984. Differentiation of ecotypes in (Oryza sativa L.). Japan Science Society, Tokyo, Elsevier, Biology of rice 7, 31-67.

United Nations, 2015. Department of Economic and Social Affairs, Population Division. World population prospects: July 2015 revision. (http://www.un.org/ en/development/desa/publications/world-populationprospects-2015-revision.html)

USDA, 2013. Economic research service. http:/www.ers. usda.gov/publications /Rice Outlook/ RCS-13e/May 14. 
USDA, 2014. United States Department of Agriculture, December, 2014. Handbook on agro-based industries ( $2^{\text {nd }}$ revised edition) by NPCS Board.

Verma, S.K., Xalxo, M.S., Saxena, R.R., Verulkarl, S.B., 2014. Identification of QTL for cold tolerance at seedling stage in rice (Oryza sativa L.). Indian Journal of Genetics 74, 86-89.

Wang, D.L., Zhu, J., Li, Z.K., Paterson, A.H., 1999. Mapping QTL with epistatic effects and QTL×environment interactions by mixed linear model approaches. Theoretical and Applied Genetics 99, 1255-1264.

Wang, Z., Wang, F., Zhou, R., Wang, J., Zhang, H., 2011. Identification of quantitative trait loci for cold tolerance during the germination and seedling stages in rice (Oryza sativa L.). Euphytica 181, 405-413.

Xiao, N., Huang,W.N., Zhang, X.X., Gao, Y., Li, A.L., Dai, Y., Yu. L., Liu, G.Q., Pan, C.H., Li, Y.H., Dai, Z.Y., Chen, J.M., 2014. Fine mapping of qRC10-2, a quantitative trait locus for cold tolerance of rice roots at seedling and mature stages. PLOS ONE 9, e96046.

Xie, G., Kato, H., Imai, R., 2012. Biochemical identification of the OsMKK6-OsMPK3 signalling pathway for chilling stress tolerance in rice. Biochemical Journal 443, 95-102.

Xie, L., Zhengwei, T., Yuan, Z., Rongbao, X., Laibao, F., Yongzhong, X., Xiaoquan, Q., 2014. Identification and fine mapping of quantitative trait loci for seed vigor in germination and seedling establishment in rice. Journal of Integrative Plant Biology 56, 749-759.

Yan, C.J., Li, X., Cheng, Z.K., Yu, H.X., Gu, M.H., Zhu, L.H., 1999. Identification of QTL for cold tolerance at early seedling stage in rice (Oryza sativa L.) via RFLP markers. Chinese Journal of Rice Science 13, 134-138.

Yang, J., Hu, C.C., Hu, H., Yu, R.D., Xia, Z., Ye, X.Z., Zhu, J., 2008. QTL Network: Mapping and visualizing genetic architecture of complex traits in experimental populations. Bioinformatics 24, 721-723.
Yang, Z., Huang, D., Tang, W., Zheng, Y., Liang, K., Cutler, A.J., 2013. Mapping of quantitative trait loci underlying cold tolerance in rice seedlings via high-throughput sequencing of pooled extremes. PLOS ONE 8, e68433.

Yoshida, S., 1981. Fundamentals of rice crop science. International Rice Research Institute, Los Banos, Philippines, 1-63.

Zhan, Q.C., Zhu, K.Y., Chen, Z.W., Zeng, S.Z., 2004. Mapping QTL controlling seedling cold tolerance in rice using $\mathrm{F}_{2}$ population. Journal of Hunan Agricultural University (Natural Sciences) 30, 303-306.

Zhang, F., Huang, L.Y., Wang, W.S., Zhao, X.Q., Zhu, L.H., 2012. Genome-wide gene expression profiling of introgressed indica rice alleles associated with seedling cold tolerance improvement in a Japonica rice background. BMC Genomics 13, 461.

Zhang, Q., Jiang, N., Wang, G.L., Hong, Y., Wang, Z., 2013. Advances in understanding cold sensing and the coldresponsive network in rice. Advances in Crop Science and Technology 1, 104.

Zhang, S., Zheng, J., Liu, B., Peng, S., Leung, H., Zhao, J., Wang, X., Yang, T., Huang, Z., 2014. Identification of QTL for cold tolerance at seedling stage in rice (Oryza sativa $\mathrm{L}$.) using two distinct methods of cold treatment. Euphytica 195, 95-104.

Zhang, Z.H., Su, L., Li, w., Chen, W., Zhu, Y.G., 2005. A major QTL conferring cold tolerance at the early seedling stage using recombinant inbred lines of rice (Oryza sativa L.). Plant Science 168, 527-534.

Zhou, L., Zeng, Y., Zheng, W., Tang, B., Yang, S., Zhang, H., Li, J., Li, Z., 2010. Fine mapping a QTL qCTB7 for cold tolerance at the booting stage on rice chromosome 7 using a near isogenic rice. Theoretical and Applied Genetics 121, 895-905. 